\title{
Karakteristik Reproduksi dan Perbedaan Respon Fisiologis Kerbau di Lahan Basah dan Lahan Kering di Kabupaten Serang Banten
}

\author{
Reproductive Characteristics and Physiological Responses of Buffalo in Wet and Dry Land at Serang District
}

\author{
Komariah$^{1}$, K. Santoso ${ }^{2}$, \& C. I. L. Siahaan ${ }^{3}$ \\ ${ }^{1}$ Laboratorium Ilmu Produksi Ternak Ruminansia Besar, Fakultas Peternakan, IPB \\ ${ }^{2}$ Laboratorium Fisiologi, Fakultas Kedokteran Hewan, IPB \\ ${ }^{3}$ Laboratorium Ilmu Produksi Ternak Ruminansia Besar, Fakultas Peternakan, IPB \\ J1. Rasamala Kampus IPB Darmaga Bogor 16680 \\ E-mail koresponden author: komariah_purjati@yahoo.com
}

\begin{abstract}
Buffalo has a higher level of adaptation than cows. The buffalo adaptation form at different locations will affect the physiological and reproduction of buffalo, so it is necessary to know buffalo adaptation on the characteristics of wetlands and dry land. This research was conducted in May to June 2017 in Kabupaten Serang, Banten. The variables observed in this research are buffalo reproduction, breeders socioeconomic, and physiological response of livestock. There were analyzed by SPSS. The results of this study indicated that buffalo reproduction characteristics in wetlands and dryland were as follows: first estrus was $22.71 \pm 7.87$ and $29.18 \pm 11.79$ months, first conception was $27.86 \pm 11.43$ and $32.55 \pm 12.12$ months, first parturition was $41.57 \pm 12.33$ and $26 \pm 12.12$ months, Calving interval was $24.10 \pm 10.39$ and $15.67 \pm 6.55$ months, calving rate was $2.36 \pm 1.15$ and $2.23 \pm 1.20$, conception period 1 year, Postpartum estroes was $6.23 \pm \mathbf{2 . 7 1}$ and $4.56 \pm \mathbf{2 . 3 4}$ months. Physiological response of livestock on dry land showed that buffalo cattle were experiencing heat stress.
\end{abstract}

Keywords: buffalo, wetlands, dry land, reproduction, physiological response

\section{PENDAHULUAN}

Kerbau (Bubalus bubalis) adalah hewan liar yang diburu untuk dikonsumsi dan kulitnya dijadikan bahan pakaian. Kerbau juga merupakan sumber daging yang mengandung protein cukup tinggi. Terdapat 2 golongan kerbau domestikasi yakni kerbau lumpur (swamp buffalo) dan kerbau sungai (Reverine buffalo). Kerbau lumpur atau rawa yang ada di Indonesia berjumlah sekitar 95\% dan sisanya dalam jumlah kecil (sekitar 2\%) adalah kerbau sungai.

Kondisi fisiologis kerbau memiliki pengaruh terhadap reproduksinya. Reproduksi yang baik dapat berdampak pada peningkatan populasi kerbau untuk memenuhi kebutuhan protein hewani masyarakat Indonesia yang masih tergolong rendah. Komariah et al. (2015) menyatakan kerbau berpotensi sebagai penunjang program swasembada daging dan ketahanan pangan nasional.

Faktor lingkungan yang mempengaruhi produktivitas ternak ialah iklim. Dibandingkan dengan sapi, pada daerah kering dimana ternak sapi kondisi tubuhnya sudah memprihatinkan (kurus), kondisi tubuh kerbau masih cukup baik. Lahan basah adalah wilayah rawa, lahan gambut, dan air baik alami maupun buatan, bersifat tetap atau sementara
, berair ladung (stagnan, static) atau mengalir yang bersifat tawar atau payau atau asin, mencakup wilayah air marin yang di dalamnya pada waktu surut tidak lebih dari enam meter (Dugan 1990)

Lahan basah adalah lahan atau tanah jenuh dengan air, baik secara permanen ataupun temporer (musiman); sebagian atau seluruhnya kadang-kadang tergenangi oleh lapisan air yang dangkal. Air yang menggenangi lahan basah dapat berupa air tawar, payau atau air asin. Lahan kering adalah lahan dengan keterbatasan sumber air sepanjang tahun dan tidak pernah dalam kondisi tergenang. Lahan kering pada umumnya memiliki daya menyerap dan menahan kelembaban rendah dan juga memiliki kandungan bahan organik tanah yang rendah pula. Kondisi ini membuat tingkat kesuburan lahan kering lebih rendah dibandingkan dengan lahan basah. Morfologi lahan kering ini bervariasi yang mencakup daerah berbukitan, datar dan bergelombang.

Kabupaten Serang merupakan salah satu kabupaten yang terletak di Provinsi Banten dengan ibukota Ciruas. Dengan luas wilayah $1467 \mathrm{~km}^{2}$ dan jumlah penduduk 1,5 juta jiwa lebih. Daerahnya terdiri atas dataran rendah, tinggi dan pesisir pantai (laut) yaitu Samudra Hindia. Fisiografi Kabupaten Serang dari arah utara ke selatan terdiri dari 
wilayah rawa pasang surut, rawa musiman, dataran, perbukitan dan pegunungan. Karakteristik reproduksi dan fisiologi kerbau belum banyak dikarakterisasi. Penelitian ini bertujuan untuk mengetahui pengaruh respon fisiologis kerbau (Bubalus bubalis) terhadap karakteristik reproduksinya di lahan basah dan lahan kering di Kabupaten Serang, Banten.

\section{MATERI DAN METODE}

\section{Waktu dan Tempat Penelitian}

Penelitian ini dilakukan di Kecamatan Cinangka sebagai kategori lahan basah dan Kecamatan Padarincang sebagai kategori lahan kering, Kabupaten Serang, Banten. Penelitian dilakukan bulan Mei sampai Juni 2017.

\section{Bahan}

Bahan yang digunakan dalam penelitian adalah kerbau (Bubalus bubalis) sebagai objek penelitian yang dipilih secara sengaja menggunakan metode pupossive sampling. Ternak terdiri dari 8 ekor kerbau betina indukan di lahan basah dan 8 ekor kerbau betina indukan di lahan kering. Jumlah peternak yang diwawancara di lahan basah sebanyak 25 orang dan 30 orang di lahan kering.

\section{Alat}

Alat yang digunakan dalam penelitian ini adalah, thermometer digital, thermohygrometer, stopwatch, borang, alat tulis, dan alat dokumentasi.

\section{Prosedur}

Penelitian ini menggunakan metode survey dan pengamatan langsung ke lokasi penelitian. Data yang dikumpulkan meliputi data primer dan data sekunder. Data primer diperoleh dari wawancara langsung dengan peternak sebagai responden menggunakan kuesioner yang sudah disiapkan. Data sekunder diperoleh dari berbagai instansi terkait, yakni Dinas Peternakan Kabupaten Serang.

\section{Analisis Deskriptif}

Analisis deskriptif digunakan untuk menggambarkan keadaan umum Kabupaten Serang berupa keadaan topografi, keadaan demografi, manajemen pemeliharaan, serta profil Kabupaten Serang Banten.

\section{Analisis Fisiologi}

Analisis fisiologi digunakan untuk mengetahui kondisi fisiologi kerbau di dua lokasi yaitu daerah basah dan kering. Data yang diamati yaitu suhu rektal, suhu lingkungan, kelembaban dan kecepatan respirasi. Suhu rektal diukur dengan memasukkan termometer ke dalam rektum sampai terdengar bunyi kemudian suhu dicatat. Suhu dan kelembapan lingkungan diperoleh dengan alat termohygrometer. Alat diletakkan di sekitar kerbau kemudian suhu dan kelembapannya di catat. Kecepatan respirasi kerbau diukur dengan cara mendekatkan tangan ke hidung kerbau dan dihitung jumlah frekuensi nafas selama satu menit. Pengukuran ini dilakukan pada tiga waktu yang berbeda yaitu pagi, siang, dan sore hari

\section{Analisis Sifat Reproduksi}

Pengamatan pada sifat reproduksi kerbau di lokasi penelitian dilakukan dengan wawancara responden. Sifat reproduksi yang diamati di dua lokasi yaitu di daerah lahan basah dan kering. Data yang diamati adalah umur pertama kali berahi (first puberty), umur pertama kali kawin (first mating), umur pertama kali melahirkan (first parturition), jarak kelahiran (calving interval), berapa kali melahirkan (calving rate), lama bunting (conception period) dan kawin setelah beranak (postpartum interval).

\section{Analisis Data}

Sifat reproduksi dan fisiologi selanjutnya dianalisis dengan menggunakan Rancangan Acak Lengkap (RAL) dengan perlakuan perbedaan daerah basah dan daerah kering dengan rumus matematik sebagai berikut menurut Steel \& Torrie (1993).

$$
Y \mathbf{i j}=\mu+T \mathbf{i}+\mathbf{c i j}
$$

Keterangan :

$\begin{array}{ll}\text { Yij } & \text { : Respon percobaan dari perlakuan ke- i dan } \\ & \text { ulangan ke-j } \\ \mu & : \text { Rataan umum } \\ \mathrm{Ti} & : \text { Efek perlakuan ke- } \mathrm{i} \\ \mathrm{Cij}_{\mathrm{ij}} & \text { : Error perlakuan ke-i dan ulangan ke-j }\end{array}$

\section{HASIL DAN PEMBAHASAN}

\section{Keadaan Umum Lokasi Penelitian}

Secara topografi, Kabupaten Serang merupakan wilayah dataran rendah dan pegunungan dengan ketinggian antara 0 sampai $1778 \mathrm{~m}$ dpl. Sebagian besar dataran rendah memiliki ketinggian kurang dari $500 \mathrm{~m}$. Curah hujan dalam sebulan rata- rata $8 \mathrm{~mm}$ dan lama hujan 12 hari. Suhu berkisar anatara $23,4{ }^{\circ} \mathrm{C}-31,8{ }^{\circ} \mathrm{C}$ dan kelembaban relatif sebesar 81\%. Luas wilayah Kecamatan Cinangka adalah 11 147 km. Luas wilayah Kecamatan Padarincang adalah 9912 $\mathrm{km}$.

Pemanfaatan wilayah Kecamatan Cinangka adalah 1 159 untuk lahan sawah dan lahan bukan sawah 6782 ha. Jumlah penduduk di Kecamatan Cinangka pada tahun 2015 sebanyak 56036 jiwa yang terdiri dari 29110 laki-laki dan 26926 perempuan. Pemanfaatan wilayah Kecamatan Padarincang 3701 untuk sawah dan 1966 untuk lahan bukan sawah. Jumlah penduduk di Kecamatan Padarincang 64481 jiwa yang terdiri dari 33111 laki-laki dan 31370 perempuan (BPS Kabupaten Serang 2017).

Berdasarkan potensinya, Banten merupakan salah satu provinsi yang akan dijadikan sentra pengembangan kerbau di Indonesia untuk mendukung swasembada daging. Populasi kerbau di Banten merupakan populasi ke-5 terbesar di Indonesia. Berdasarkan data BPS (2017), kabupaten Serang memiliki jumlah populasi ternak kerbau sebanyak 21634 ST pada tahun 2010, meningkat pada tahun 2011 sebanyak 30596 ST, pada tahun 2012 sebanyak 30857 ST, pada tahun 2013 sebanyak 25621 ST, dan tahun 2014 sebanyak 26385 ST.

\section{Karakteristik Peternak}

Peternak di kedua kecamatan sebagian besar merupakan petani. Beternak merupakan usaha sambilan seraya bertani. Karakteristik pendidikan peternak di dua 
Kecamatan masih tergolong sangat rendah yaitu tamat SD sebanyak 83,33\% dan tidak bersekolah sebanyak 8,33\% Tabel 1). Meskipun pendidikan peternak tersebut rendah, peternak rata-rata sudah memiliki pengalaman berternak mulai dari 10 tahun sampai 30 tahun. Sebanyak 79,17\% peternak di daerah lahan basah memiliki pengalaman beternak lebih dari 10 tahun dan sebanyak 56,67\% peternak di lahan kering memiliki pengalaman beternak 10 tahun atau lebih. Menurut Utami (2016) pengalaman beternak sangat berpengaruh terhadap keberhasilan usaha. Semakin lama seseorang memiliki pengelaman beternak akan semakin mudah peternak mengatasi kesulitan kesulitan yang dialaminya.

Skala kepemilikan kerbau antara satu atau dua ekor ternak. Untuk kategori lahan basah, Kecamatan Cinangka bibit sebagian besar berasal dari pemerintah. Kerbau diberikan kepada peternak untuk dikelola dan hasilnya dibagi dua dengan pemerintah. Di daerah lahan kering, yaitu

Tabel 1. Sosial Ekonomi Peternak

\begin{tabular}{|c|c|c|c|c|}
\hline \multirow[t]{2}{*}{ Karakteristik Peternak Kerbau } & \multicolumn{2}{|c|}{ Lahan basah } & \multicolumn{2}{|c|}{ Lahan Kering } \\
\hline & Responden (org) & Persentase & Responden (org) & Persentase \\
\hline \multicolumn{5}{|l|}{ Pendidikan } \\
\hline Tidak sekolah & 2 & 8,33 & 3 & 10,00 \\
\hline $\mathrm{SD}$ & 20 & 83,33 & 25 & 83,33 \\
\hline SMP & 1 & 4,17 & 0 & 0,00 \\
\hline SMA & 1 & 4,17 & 1 & 3,33 \\
\hline Sarjana & 0 & 0,00 & 1 & 3,33 \\
\hline \multicolumn{5}{|l|}{ Pengalaman Beternak Kerbau } \\
\hline $0-10$ & 19 & 79,17 & 17 & 56,67 \\
\hline 11 & 4 & 16,67 & 10 & 33,33 \\
\hline $21-30$ & 1 & 4,17 & 3 & 10,00 \\
\hline \multicolumn{5}{|l|}{ Jumlah Kerbau yang Dimiliki } \\
\hline 1 & 12 & 50 & 16 & 53,33 \\
\hline 2 & 11 & 45,83 & 7 & 23,33 \\
\hline 3 & 0 & 0 & 4 & 13,33 \\
\hline$>=4$ & 1 & 4,17 & 3 & 10,00 \\
\hline \multicolumn{5}{|l|}{ Bibit Berasal Dari } \\
\hline Beli di peternak lain & 6 & 25 & 12 & 40 \\
\hline Orang yang menitipkan & 2 & 8,33 & 11 & 36,67 \\
\hline Pemerintah & 16 & 66,67 & 1 & 3,33 \\
\hline dll (warisan) & 0 & 0,00 & 6 & 20 \\
\hline \multicolumn{5}{|l|}{ Jenis Pakan yang diberikan } \\
\hline Hijauan & 21 & 87,50 & 29 & 96,67 \\
\hline Konsentrat & 1 & 4,17 & 0 & 0,00 \\
\hline Hijauan dan konsentrat & 2 & 8,33 & 1 & 3,33 \\
\hline \multicolumn{5}{|c|}{ Apakah dibutuhkan silsilah yang jelas sebelum membeli ternak } \\
\hline Ya & 1 & 4,17 & 0 & 0 \\
\hline Tidak & 23 & 95,83 & 30 & 100 \\
\hline \multicolumn{5}{|l|}{ Pemberian obat/ vitamin } \\
\hline Pernah & 13 & 54,17 & 20 & 66,67 \\
\hline Tidak pernah & 11 & 45,83 & 10 & 33,33 \\
\hline \multicolumn{5}{|l|}{ Bagaimana cara mengobati } \\
\hline Ditangani sendiri & 13 & 54,17 & 20 & 66,67 \\
\hline Memanggil peternak yang berpengalaman & 0 & 0,00 & 0 & 0,00 \\
\hline Memanggil dokter hewan & 2 & 8,33 & 5 & 16,67 \\
\hline dll (tidak pernah sakit ) & 9 & 37,50 & 5 & 16,67 \\
\hline \multicolumn{5}{|c|}{ Apakah jika terdapat penyakit serius, langsung dikonsultasikan dengan dokter hewan } \\
\hline Ya & 14 & 58,33 & 11 & 36,67 \\
\hline Tidak, karena & 10 & 41,67 & 19 & 63,33 \\
\hline
\end{tabular}


Kecamatan Padarincang bibit berasal dari peternak lain dan warisan dari orang tua.

Beberapa peternak yang kerbaunya tidak berasal dari pemerintah, biasanya membeli kerbau betina yang masih kecil untuk dikembangkan. Peternak tidak terlalu berorientasi pada keuntungan, kerbau dipelihara dengan pengalaman seadanya dan tidak memperhatikan adanya kemungkinan inbreeding. Peternak menggunakan kerbau sebagai tabungan yang sewaktu-waktu dapat dijual untuk memenuhi kebutuhan misalnya untuk membayar sekolah anak, membayar biaya rumah sakit keluarga dan lainlain. Hal tersebut menyebabkan populasi ternak tidak berkembang.

Performa reproduksi dipengaruhi oleh beberapa faktor yaitu faktor genetik, pakan dan lingkungan (Komariah et al. 2015). Pakan yang diberikan oleh peternak di lahan basah dan lahan kering berasal dari hijauan yang tumbuh di sekitar kebun. Jenis hijauan yang diberikan oleh peternak di lahan basah dan di lahan kering adalah rumput gajah dan Brachiaria humidicolla.

Menurut Handoko (1994) iklim dan kondisi lingkungan sangat berpengaruh terhadap ketersediaan mineral dari pakan hijauan. Di daerah kering dengan curah hujan rendah, kandungan mineral hijauan lebih rendah disbanding daerah dengan curah hujan tinggi, hal ini akan berpengaruh pada pencapaian pubertas ternak.

Peternak yang memberikan obat atau vitamin di daerah lahan basah sebanyak 54\% sedangkan di lahan kering sebanyak $66 \%$, sisanya tidak pernah karena kerbau jarang terkena penyakit. Peternak diberi oleh pemerintah vitamin ternak ketika dilaksanakan sosialisasi kesehatan ternak. Ternak di lahan basah tidak banyak terkena penyakit, meskipun ada beberapa kerbau yang terkena penyakit cacing dan mencret. Ternak di lahan kering banyak terserang mencret dan panas. Apabila ternak kerbau sakit, peternak menangani sendiri. Peternak biasanya menggunakan tanaman yang diakui berkhasiat sebagai obat. Peternak tidak membawa ke mantri karena mantri jarang ditemukan di desa baik lahan kering.

\section{Karakteristik Reproduksi}

Jenis kerbau yang dipelihara di Kecamatan Cinangka dan Kecamatan Padarincang adalah kerbau rawa. Kerbau ini tampak lebih liar dibandingkan kerbau tipe sungai. Fahimuddin (1975) menyatakan bahwa kerbau rawa merupakan kerbau pendek, gemuk dan bertanduk panjang.

Pada umumnya kerbau di lahan basah dan di lahan kering tidak memiliki terlalu banyak perbedaan karena kerbau di kedua kecamatan adalah kerbau dengan spesies yang sama. Akan tetapi apabila dilihat secara teliti terdapat beberapa perbedaan kerbau di kedua lahan tersebut. Kerbau di lahan basah berwarna abu-abu terang dan memiliki bulu yang agak panjang sedangkan di lahan kering kerbau berwarna abu-abu gelap dan bulu yang sedikit atau hampir tidak ada. Menurut Dudi et al. (2011) variasi warna kulit kerbau ini merupakan manifestasi antara satu atau beberapa pasang gen. Selain itu dari sisi penampilan, kerbau di lahan basah terlihat lebih jinak jika dibandingkan dengan kerbau di lahan kering.
Kerbau dibagi dalam 3 pengelompokan yaitu kerbau dengan kelompok umur 1-5 tahun, 6-10 tahun, dan 11-15 tahun (Tabel 2, 3, dan 4). Berdasarkan penelitian yang telah dilakukan di dua kecamatan, sesuai Tabel 2, 3, dan 4 diketahui bahwa umur pertama kali berahi kerbau berdasarkan kelompok umur 1-5 tahun tidak signifikan antara lahan basah dan lahan kering. Para peternak di lokasi penelitian tidak begitu mengetahui tanda-tanda berahi pada ternak kerbau mereka. Hal ini dapat menyebabkan kurang efektifnya perkawinan karena waktu birahi kerbau bisa saja sudah terlewat saat peternak mengawinkan kerbau.

Menurut Toelihere (1980), tanda-tanda birahi pada ternak kerbau adalah vulva membengkak dan mengeluarkan lendir berwarna bening pada sore hari setelah digembalakan. Pengeluaran lendir tersebut akan terlihat jelas ketika kerbau dalam keadaan terbaring, karena perut yang tertekan akan mendorong keluarnya lendir tersebut yang akan jatuh ke tempat berbaring.

Umur kawin pertama kerbau lumpur di daerah lahan basah pada kelompok umur 1-5 tahun adalah 2,3 tahun, kelompok umur 6-10 tahun pada umur 2,25 tahun dan pada kelompok usia 11-15 tahun adalah usia 3 tahun. Di daerah lahan kering umur kawin pertama kerbau pada kelompok umur 1-5 tahun adalah 3 tahun, pada kelompok umur $6-10$ tahun adalah 2,6 tahun, dan kelompok umur 11-15 tahun adalah 2,9 tahun. Umur kawin pertama kerbau lumpur menurut Chantalakhana (1980) adalah 2,5 tahun. Umur kawin pertama di lahan kering lebih lama dibandingkan dengan umur kawin pertama di lahan basah, hal ini dapat disebabkan oleh kawin terlewat akibat berahi tidak terdekteksi oleh peternak atau faktor lingkungan yang dapat berpengaruh terhadap hormon kerbau.

Lama bunting kerbau di kedua lahan sebagian besar adalah 12 bulan, pada lahan basah kelompok umur 1-5 tahun dan lahan kering kelompok umur 11-15 tahun lama bunting kerbau adalah 11,75 $\pm 0,71$ dan $11,25 \pm 1,50$. Hal tersebut tidak jauh berbeda dengan hasil penelitian Toelihere (1980) yang menyatakan bahwa lama bunting kerbau di Asia Tenggara adalah 11.3 bulan. Lama bunting merupakan suatu aspek yang mempengaruhi selang beranak (Lendhanie 2005). Perbedaan lama kebuntingan bisa disebabkan oleh manajemen pemeliharaan, pakan dan iklim lingkungan.

Rabie (2011) menyatakan kerbau betina biasanya melahirkan pertama kali pada umur 5 tahun. Umur pertama kali melahirkan kerbau di kedua lahan lebih cepat yaitu 3,2 tahun, 3,4 dan 3,6 tahun. Umur pertama kali melahirkan dipengaruhi oleh umur pertama kali kawin kerbau. Menurut Mufidah (2013) hal ini dapat disebabkan oleh tidak adanya pengontrolan dari peternak sehingga perkawinan dapat terjadi kapan saja terutama saat di gembalakan.

Jarak kelahiran (calving internal) ternak kerbau pada penelitian di lahan basah dan kering pada kelompok umur 6-10 adalah 24,10 $\pm 10,39$ dan 15,67 $\pm 6,55$. Menurut Guzman (1980) jarak kelahiran kerbau rawa berkisar antara 1-3 tahun atau rata-rata 1,5 tahun. Sesuai penelitian Yendraliza (2010)

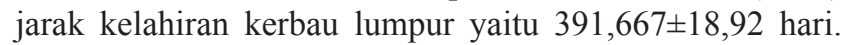
Jarak kelahiran dipengaruhi oleh berahi pertama setelah beranak dan lama bunting. Semakin lama ternak berahi setelah melahirkan maka jarak kelahiran semakin lama. 
Tabel 2. Karakteristik Reproduksi Kerbau Pada Umur 1-5 Tahun

\begin{tabular}{lccccc}
\hline Sifat Reproduksi & \multicolumn{2}{c}{ Lahan Basah } & \multicolumn{2}{c}{ Lahan Kering } & \multirow{2}{*}{ Sig } \\
\cline { 2 - 5 } & Performa & Jumlah (n) & Performa & Jumlah (n) & \\
\hline Umur pertama kali birahi (bulan) & $17,25 \pm 5,95$ & 8 & $28,50 \pm 16,52$ & 4 & 0,003 \\
Umur pertama kali kawin (bulan) & $28,75 \pm 7,09$ & 8 & $36,00 \pm 12,0$ & 3 & 0,520 \\
Umur pertama kali melahirkan (bulan) & $39,00 \pm 8,49$ & 8 & $29,30 \pm 28,38$ & 3 & 0,230 \\
Jarak kelahiran (bulan) & $15,33 \pm 3,06$ & 3 & & 3 & 0,800 \\
Berapa kali melahirkan & $1,28 \pm 0,49$ & 7 & $0,70 \pm 0,58$ & 3 & 0,200 \\
Lama bunting (bulan) & $11,75 \pm 0,71$ & 8 & $12,00 \pm 0,00$ & 3 & 0,270 \\
Kawin setelah beranak (bulan) & $5,28 \pm 1,50$ & 7 & $6,50 \pm 0,71$ & 2 & \\
\hline
\end{tabular}

Tabel 3. Karakteristik Reproduksi Kerbau Pada Umur 6-10 Tahun

\begin{tabular}{lccccc}
\hline Sifat Reproduksi & \multicolumn{2}{c}{ Lahan Basah } & \multicolumn{2}{c}{ Lahan Kering } & \multirow{2}{*}{ Sig } \\
\cline { 2 - 5 } & Performa & Jumlah (n) & Performa & Jumlah (n) & \\
\hline Umur pertama kali birahi (bulan) & $22,71 \pm 7,87$ & 14 & $29,18 \pm 11,79$ & 17 & 0,050 \\
Umur pertama kali kawin (bulan) & $27,86 \pm 11,43$ & 14 & $32,55 \pm 12,12$ & 20 & 0,910 \\
Umur pertama kali melahirkan (bulan) & $41,57 \pm 12,33$ & 14 & $26,04 \pm 22,09$ & 23 & 0,002 \\
Jarak kelahiran (bulan) & $24,10 \pm 10,39$ & 10 & $15,67 \pm 6,55$ & 18 & 0,290 \\
Berapa kali melahirkan & $2,36 \pm 1,15$ & 14 & $2,23 \pm 1,20$ & 24 & 0,890 \\
Lama bunting (bulan) & $12,00 \pm 0,00$ & 14 & $12,00 \pm 0,00$ & 24 & 0,007 \\
\hline
\end{tabular}

Tabel 4. Karakteristik Reproduksi Kerbau Pada Umur 11-15 Tahun

\begin{tabular}{lccccc}
\hline Sifat Reproduksi & \multicolumn{2}{c}{ Lahan Basah } & \multicolumn{2}{c}{ Lahan Kering } & \multirow{2}{*}{ Sig } \\
\cline { 2 - 5 } & Performa & Jumlah (n) & Performa & Jumlah (n) & \\
\hline Umur pertama kali birahi (bulan) & $18,00 \pm 6,00$ & 3 & $28,50 \pm 5,47$ & 4 & 1,00 \\
Umur pertama kali kawin (bulan) & $36,00 \pm 12,00$ & 3 & $35,50 \pm 1,00$ & 4 & 0,15 \\
Umur pertama kali melahirkan (bulan) & $44,00 \pm 18,33$ & 3 & $27,00 \pm 24,37$ & 4 & 0,48 \\
Jarak kelahiran (bulan) & $18,00 \pm 0,00$ & 2 & $12,00 \pm 0,00$ & 3 & 0,05 \\
Berapa kali melahirkan & $2,67 \pm 1,53$ & 3 & $3,63 \pm 1,49$ & 4 & 0,72 \\
Lama bunting (bulan) & $12,00 \pm 0,00$ & 3 & $11,25 \pm 1,50$ & 4 & 0,16 \\
Kawin setelah beranak (bulan) & $6,00 \pm 4,24$ & 2 & $6,00 \pm 1,41$ & & 2 \\
\hline
\end{tabular}

Hal ini juga berkaitan dengan kemampuan peternak dalam mendeteksi berahi pada kerbau.

Jumlah melahirkan kerbau pada kelompok umur 1-5 tahun pada lahan basah adalah 1,28 dan lahan kering adalah 0,7 , data ini menunjukkan bahwa dibandingkan dengan lahan kering, pada umur tersebut angka kelahiran kerbau di lahan basah lebih tinggi. Pada kelompok umur 6-10 tahun, jumlah melahirkan kerbau pada lahan basah adalah 2,36 dan di lahan kering adalah 2,23. Kelompok umur 11-15 tahun jumlah melahirkan kerbau di lahan basah adalah 2,67 dan di lahan kering 3,63, dari kedua kelompok umur tersebut lahan basah lebih rendah nilainya dibandingkan dengan lahan kering. Faktor yang memepengaruhi angka kelahiran adalah keberhasilan perkawinan antara jantan dan betina (Samsuandi 2016).

Berdasarkan penelitian Lendhanie (2005) kerbau rawa berahi kembali setelah kawin pada 3-5 bulan. Hasil penelitian menunjukkan rata-rata periode waktu yang dibutuhkan kerbau kawin kembali setelah beranak adalah 6 bulan. Hal ini disebabkan adanya faktor proses involusi uterus yang lebih lama terjadi pada kerbau (Komariah et al. 2015)

\section{Respon Fisiologis}

Berikut merupakan hasil regresi linear sederhana parameter lingkungan dan respon fisiologis kerbau pada lokasi yang berbeda (Gambar 1 dan 2). Penelitian dilakukan di Kecamatan Cinangka sebagai kategori lahan basah, Kecamatan Padarincang sebagai kategori lahan kering, kabupaten Serang, provinsi Banten. Parameter yang diukur adalah suhu rektal, respirasi, suhu lingkungan, dan kelembaban. Pengambilan data dilakukan sebanyak tiga kali yaitu pagi pukul 09.00 , siang pukul 12.00 , dan sore pukul 15.00 WIB.

Melalui Gambar 1 dan 2 dijelaskan mengenai perbandingan antara respirasi, suhu, suhu rektal, dan kelembapan pada lahan basah dan lahan kering. Dari Gambar 1 dapat diketahui bahwa nilai respirasi pada lahan basah adalah $\mathrm{Y}=0,317 \mathrm{x}+14,873$ artinya waktu berpengaruh positif terhadap respirasi sebesar 0,317 per satuan waktu, sedangkan untuk lahan kering $\mathrm{Y}=0,6381 \mathrm{x}+11,507$ artinya 

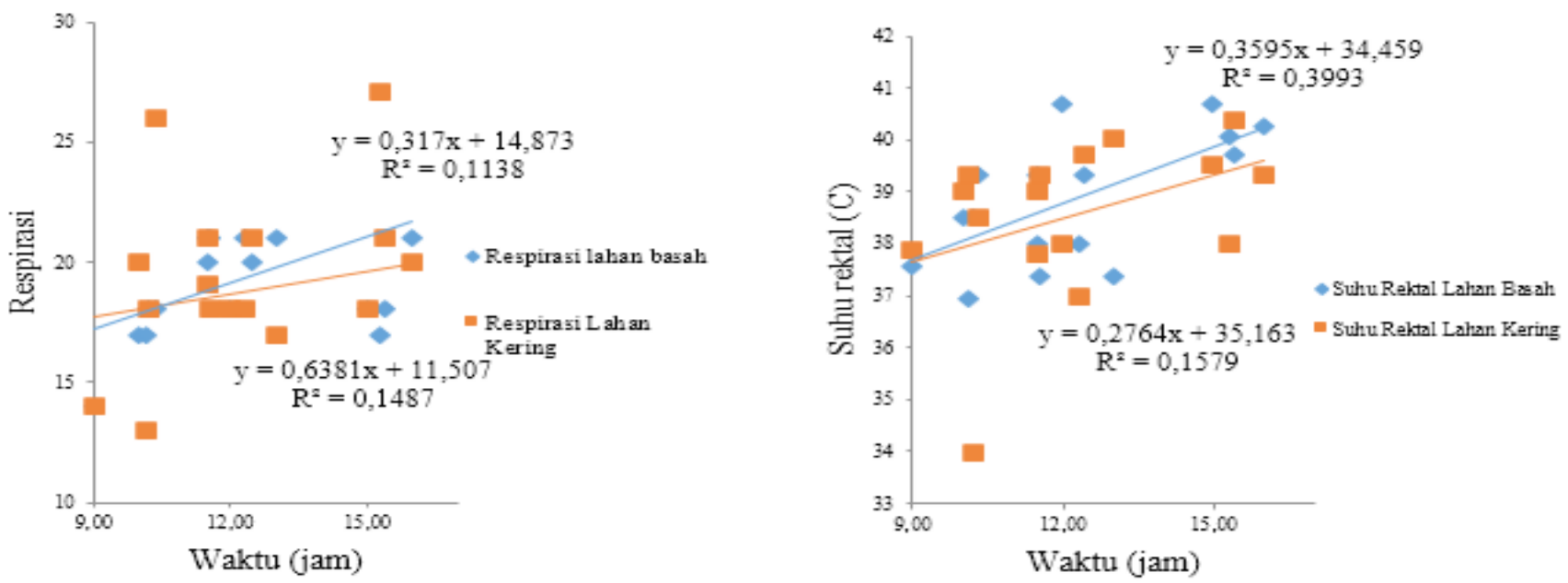

Gambar 1. Regresi linear sederhana respirasi dan suhu rektal kerbau
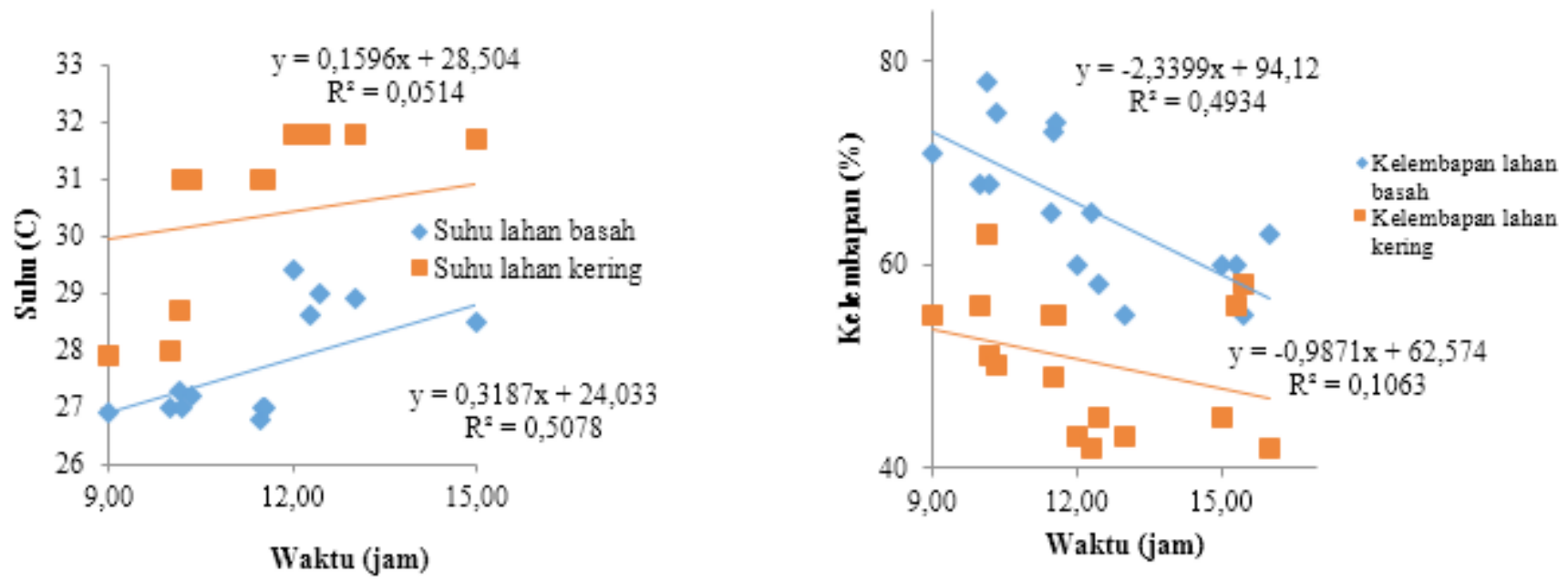

Gambar 2. Regresi linear sederhana suhu dan kelembaban lingkungan tinggal kerbau

waktu mempengaruhi respirasi sebesar 0,6381 per satuan waktu.

Nilai $\mathrm{R}$ untuk kedua lahan berada pada nilai 0,1 yang berarti bahwa besarnya angka koefisien determinasi adalah 0,1 sama dengan 10. Angka tersebut mengandung arti bahwa waktu berpengaruh terhadap respirasi sebesar $10 \%$ sedangkan sisanya dapat dipengaruhi oleh faktor lain. Suhu lingkungan yang tinggi menyebabkan kerbau memberi respon dengan cara beradaptasi secara fisiologis melalui perubahan tingkah laku berupa panting, berkubang atau berbaring di tempat dingin. Hal ini juga menyebabkan laju respirasi dan denyut jantung meningkat (Hafez 1993).

Suhu rektal kerbau di lahan basah dan lahan kering dijelaskan melalui Gambar 2. Nilai suhu rektal kerbau di lahan basah adalah $\mathrm{Y}=0,395 \mathrm{x}+34,459$ yang artinya waktu berpengaruh positif terhadap suhu rektal sebesar 0,395 sedangkan dilahan kering adalah $\mathrm{Y}=0,2764 \mathrm{x}+35,163$ artinya waktu berpengaruh positif terhadap suhu rektal sebesar 0,276 per satuan waktu. Pada Tabel 3 dijelaskan bahwa suhu rektal kerbau di kedua lahan meningkat seiring pertambahan waktu. Menurut Recee et al. (2015) peningkatan suhu rektal ini disebabkan oleh panas hasil metabolisme dalam tubuh.

Menurut Williamson dan Payne (1993), suhu lingkungan turun sebesar $1,7{ }^{\circ} \mathrm{C}$ setiap kenaikan $305 \mathrm{~m}$. Suhu lingkungan dan kelembaban udara dipengaruhi oleh intensitas cahaya matahari dan konveksi energi matahari. Kerapatan gas penyusun troposfer, yang merupakan lapisan atmosfer paling dekat dengan bumi, akan semakin kecil seiring dengan bertambahnya ketinggian. Hal ini disebakan oleh medan gravitasi menarik partikel gas ke permukan bumi (Seinfield dan Pandis 2006).

Pada Tabel 5 dan 6 diketahui nilai suhu dan kelembaban di kedua lahan berbeda. Kelembaban di lahan basah dan kering tinggi pada pagi hari dan menurun pada siang dan sore hari. Rata-rata suhu di lahan basah dan lahan kering pada pagi hari adalah $27-29{ }^{\circ} \mathrm{C}$, pada siang hari meningkat $29-30{ }^{\circ} \mathrm{C}$, sedangkan pada sore hari $28{ }^{\circ} \mathrm{C}$ di lahan basah tetapi meningkat di $31^{\circ} \mathrm{C}$ di lahan kering. Suhu yang di teliti di kedua lahan menunjukkan kerbau tidak berada pada suhu nyamannya.

Menurut Fahimuddin (1975) perbedaan kondisi 
Tabel 5. Rataan respon fisiologis kerbau di lokasi yang berbeda

\begin{tabular}{lcccccc}
\hline Respon Fisologis & \multicolumn{3}{c}{ Lahan Basah } & \multicolumn{3}{c}{ Lahan Kering } \\
\cline { 2 - 7 } & Pagi & Siang & Sore & Pagi & Siang & Sore \\
\hline Suhu Rectal $\left({ }^{\circ} \mathrm{C}\right)$ & $38,2 \pm 0,9$ & $38,8 \pm 1,5$ & $40,2 \pm 0,4$ & $38,1 \pm 1,8$ & $38,7 \pm 1,4$ & $39,3 \pm 1,0$ \\
Respirasi & $18,3 \pm 2,4$ & $20,0 \pm 1,4$ & $18,50 \pm 1,7$ & $18,6 \pm 4,1$ & $18,5 \pm 1,7$ & $21,5 \pm 3,9$ \\
\hline
\end{tabular}

Tabel 6. Rataan parameter lingkungan hidup kerbau

\begin{tabular}{lcccccc}
\hline Parameter Lingkungan & \multicolumn{3}{c}{ Lahan Basah } & \multicolumn{3}{c}{ Lahan Kering } \\
\cline { 2 - 7 } & Pagi & Siang & Sore & Pagi & Siang & Sore \\
\hline T $\left({ }^{\circ} \mathrm{C}\right)$ & $27,0 \pm 0,2$ & $30,0 \pm 0,3$ & $28,7 \pm 0,4$ & $30,0 \pm 1,4$ & $30,1 \pm 1,9$ & $31,8 \pm 0,00$ \\
RH $(\%)$ & $71,5 \pm 4,0$ & $59,5 \pm 4,2$ & $59,5 \pm 3,3$ & $54,3 \pm 4,2$ & $50,3 \pm 7,9$ & $43,3 \pm 1,3$ \\
\hline
\end{tabular}

lingkungan di kedua lahan dapat mempengaruhi kondisi fisiologis kerbau. Selanjutnya dikatakan suhu nyaman kerbau adalah $15,5-21,0{ }^{\circ} \mathrm{C}$. Dengan suhu yang diteliti pada kedua lahan, kerbau kemungkinan mengalami heat stress yang dapat berpengaruh terhadap reproduksinya. Iklim seperti suhu dan kelembaban udara akan nyata mempengaruhi respon fisiologi ternak, seperti suhu rektal, frekuensi pernapasan, dan denyut jantung. Lingkungan dapat berpengaruh secara langsung dan tidak langsung terhadap ternak. Pengaruh lingkungan secara langsung yaitu terhadap tingkat produksi sedangkan pengaruh tidak langsung berhubungan dengan kualitas dan ketersediaan pakan (Purwanto et al. 1991).

\section{KESIMPULAN}

Karakteristik reproduksi kerbau di lahan basah dan lahan kering menunjukkan pertama kali birahi berkisar 2229 bulan dengan umur pertama dikawinkan berkisar 2732 bulan. Umur pertama kali melahirkan sekitar 41 bulan dengan jarak beranak 15-24 bulan. Respon fisiologis ternak kerbau sangat dipengaruhi oleh keadaan iklim seperti suhu dan kelembaban. Respon fisiologis kerbau di lahan kering mengalami heat stress yang ditunjukkan melalui frekuensi nafas meningkat, dan suhu rektal tinggi.

\section{DAFTAR PUSTAKA}

(BPS) Badan Pusat Statistik Kabupaten Cianjur. 2017. Kabupaten Serang Dalam Angka 2017. BPS Kabupaten Serang.

(DISPERTA) Dinas Pertanian, Kehutanan, Perkebunan dan Peternakan Kabupaten Serang. http://disperta. serangkab.go.id/ Profil Daerah Kabupaten Serang.

Chantalakhana, \& P. Skunmun. 2002. Sustainable Smallholder Animal Systems in the Tropics. Kasetsart University Pr. Bangkok.

Dudi, C. Sumantri, H. Martojo, A. Anang. 2011. Keragaan sifat kualitatif dan kuantitatif kerbau lokal di provinsi Banten. Jurnal Ilmu Ternak. 11(2): 61-67.

Dugan, P. J. 1990. Wetland Conservation. The World Conservation Union. Gland, Switzerland.

Fahimuddin, M. 1975. Domestic water buffallo. New Delhi (IND): IBH publishing co.

Guzman, M. R. 1980. An overview of recent development in buffalo research and management in Asia. Dalam: Buffalo Production for Small Farms. ASPAC, Taipei.

Hafez, E. S. 1993. Reproduction in Farm Animal 5 th Ed. Lea and Febiger. Philadelphia

Handoko. 1994. Klimatologi Dasar, Landasan Pemahaman Fisika Atmosfer dan Unsur-Unsur Iklim. PT. Dunia Pustaka Jaya. Jakarta.

Komariah, C. Sumantri, H. Nuraini, S.Mulatsih, \& S. Nurdiati. 2015. Performans Kerbau Lumpur dan Strategi Pengembangannya pada Daerah dengan Ketinggian Berbeda di Kabupaten Cianjur. Jurnal Veteriner. 16(4):606-615.

Lendhanie, U. 2005. Karakteristik reproduksi kerbau rawa dalam kondisi lingkungan peternakan rakyat. Kalimantan Selatan. Bioscientiae. 1(2):43-48.

Madan, M. L., S. K. Das, \& P. Palta. 1996. Application of reproductive technology to buffaloes. J Anim Reprod Sci. (42):299-306.

Mufidah. 2013. Produktivitas induk kerbau rawa (bubalus bubalis) ditinjau aspek kinerja reproduksi dan ukuran tubuh di Kecamatan Tempursari Kabupaten Lumajang. Jurnal Ternak Tropika. 14(1):21-28.

Payne, R. C., I. P. Sukanto, D. Diauham, S. Partoutomo, A. J. Wuson, T. W. Jones, R. Bold, \& A. G. Luckins. 1991. 
Trypanosoma evansi infection in cattle, buffaloes and horsesin Indonesia. J Vet Parasitol. 38:109-119.

Samsuandi. 2016. Performans Reproduksi Kerbau Lumpur (bubalus bubalis) Betina di Kecamatan Simeulue Barat Kabupaten Simeulue. Jurnal Ilmiah Mahasiswa Pertanian Unsyiah. 1(1): 665-670.

Toelihere, M. R. 1980. Fisiologi Reproduksi pada Ternak. Bandung (ID): Angkasa.

Talib, C., T. Herawati, \& Hastono. 2014. Strategi peningkatan produktivitas kerbau melalui perbaikan pakan dan genetik. Wartazoa. 24(2):83-96.

Utami, L. S., B. Syahdar, \& S. T. Sirajuddin. 2016. Hubungan karakteristik peternak dengan skala usaha ternak kerbau di Desa Sumbang Kecamatan curio Kabupaten Enrekang. 4(3):146-150.
Williamson, G., \& W. J. A. Payne. 1993. Pengantar Peternakan di Daerah Tropis. Terjemahan: Darmadja D. Gadjah Mada Press. Yogyakarta.

Yendraliza. 2010. Karakteristik Reproduksi Kerbau Lumpur (Swamp Buffalo) Betina Di Kabupaten Kampar. Seminar nasional Teknologi Peternakan dan Veteriner 2010.

Yurleni. 2000. Produktivitas dan peluang pengembangan ternak kerbau di Propinsi Jambi. Tesis. Bogor (ID): Institut Pertanian Bogor. 